\title{
Place-Centered or Person-Centered? Considerations about the Behavioral Mapping Approach
}

\author{
Camila Klein ${ }^{1, *}$ \\ Orcid.org/0000-0002-6785-0355 \\ Ariane Kuhnen ${ }^{1}$ \\ Orcid.org/0000-0001-9635-9306 \\ Maíra Longhinotti Felippe ${ }^{1}$ \\ Orcid.org/0000-0001-9483-1654 \\ Bertiele Barboza Silveira ${ }^{1}$ \\ Orcid.org/0000-0002-1935-3004
}

${ }^{1}$ Universidade Federal de Santa Catarina, Florianópolis, SC, Brasil

\begin{abstract}
This paper focus on the technique of Behavioral Mapping (BM), and discusses about its application objectives face to the nomenclature it receives. Therefore, presents a review of empical studies conductec between 2005 and 2015. Through technique of agreement among evaluators, the fourteen selected papers were examined according to the following criteria: the department that held the research, theoretical framework, objectives and hipothesis, content of the discussion and content of final considerations. From that, the judges defined the emphasis of the articles (person or environment) and evaluated the BM design developed compared to the research goals. This paper also discussed the employed nomenclature, considering that international studies only use "behavioral mapping" and not use the complements "place centered" or "person centered", commonly found in the national literature. International studies are concerned to define the research problem, and the instrument of BM is built based on the research objectives, assuming varied designs and application modes. Finally, it was proposed to adopt the nomenclature "behavioral mapping" since it shows up enough and wide, so that allows the creation of instrument designs adapted to the demands of the research.
\end{abstract}

Keywords: Behavioral mapping, observational method, person-environment studies.

* Mailing address: Universidade Federal de Santa Catarina, Departamento de Psicologia, AC Cidade Universitária, Trindade, Florianópolis, SC, Brazil 88040970. E-mail: kleincamila.ck@gmail.com, ariane.kuhnen@ufsc.br, mairafelippe@gmail.com and bettieli.bs@gmail.com

Support: Coordenação de Aperfeiçoamento de Pessoal de Nível Superior (CAPES); Fundação de Amparo à Pesquisa e Inovação do Estado de Santa Catarina (FAPESC). 


\section{Centrado no Lugar ou na Pessoa? Considerações acerca de Foco no Mapeamento Comportamental}

\section{Resumo}

Este trabalho debateu a técnica do Mapeamento Comportamental (MC), tecendo uma reflexão acerca dos objetivos de sua aplicação em função da nomenclatura que recebem. Para tal, apresenta uma revisão de estudos empíricos realizados entre 2005 e 2015. Por meio de análise de juízes, os 14 estudos que compuseram a revisão foram examinados de acordo com os seguintes quesitos: departamentos de origem do estudo, referenciais teóricos utilizados, pergunta ou tema de pesquisa, conteúdo da discussão e conteúdo das considerações finais. A partir disso, os juízes definiram a ênfase dos artigos, se na pessoa ou no ambiente, bem como avaliaram o desenho de MC desenvolvido face aos objetivos. Discutiu-se o tipo da nomenclatura empregada, tendo em vista que os estudos internacionais fazem uso da expressão "mapeamento comportamental" e não utilizam os complementos "centrado no lugar" ou "centrado na pessoa" encontrados na literatura nacional. Os estudos internacionais preocupam-se em delinear o problema de pesquisa, e o instrumento é construído a partir das hipóteses ou objetivos, assumindo variados desenhos e modos de aplicação. Finalmente, propôs-se a adoção da nomenclatura "mapeamento comportamental" já que esta demonstra-se suficiente e ampla, de modo que permite a criação de desenhos de instrumento adaptados às demandas da pesquisa.

Palavras-chave: Mapeamento comportamental, método observacional, estudos pessoa-ambiente.

\section{Centrar en el Sitio o en la Persona? Consideraciones sobre la Énfasis del Mapeo del Comportamiento}

\section{Resumen}

Este trabajo discute la técnica de Mapeo del Comportamiento (MC), abriendo una reflexión acerca de los objetivos de su aplicación y sobre la nomenclatura que reciben, y presenta una revisión de estudios empíricos llevados a cabo entre 2005 y 2015. Los 14 estudios que se incluyeron en la revisión fueron examinados por jueces que definen el énfasis de los artículos, si es la persona o si es el medio ambiente, así como también evaluan si el diseño desarrollado por el MC cumple los objetivos iniciales. Se discutió el tipo de nomenclatura empleada, teniendo en cuenta que en los estudios internacionales se utiliza la expresión de "mapeo del comportamiento" pero no utilizan los complementos "énfasis en el medio ambiente" ni "énfasis en la persona", como en la literatura nacional. Los estudios internacionales están interesados en la definición del problema de investigación, y el instrumento se construye a partir de las hipótesis u objetivos, asumiendo variados diseños y modos de aplicación. Por último, se propone la adopción de la nomenclatura "mapeo del comportamiento", ya que demuestra ser suficiente y amplio, de manera que permite la creación de diseños de instrumentos adaptados a las exigencias de la investigación.

Palabras clave: Mapeo del comportamento, método de observación, estudios persona-ambiente.

\section{Behavioral Mapping in Observational Studies}

In the epigraph of his acclaimed book Blindness, Nobel Prize-winning author José Saramago (2005) opens the novel with a provocative remark: "If you can see, look. If you can look, observe". In fact, perhaps one of the great pleasures of mankind is simply to observe, or better still, notice, which implies realization and awareness. People enjoy watching the sunset, looking at people who walk down the street, or contemplating a work of art. When able to do so, humans are impelled to observe, with greater 
or lesser attention, the surrounding physical and social environment. In the field of science, this is no different: observation is an important research method and technique, both in exact sciences and in human sciences, for example.

The use of direct observation techniques is especially useful when information relevant to research cannot be collected through participants' verbal or non-verbal self-reports (e.g., interviews and photographs, respectively). Unlike observation techniques, personal accounts depend on the respondent's willingness and ability to provide information to the researcher (Günther, Elali, \& Pinheiro, 2008; Günther, 2008). Reports also inform perceptions of behavior which are subject to the influence of the respondent's memory, knowledge, beliefs, values and aspirations (Corral-Verdugo \& Pinheiro, 1999). In addition, people are not always aware of how they act toward the environment and, therefore, even if they wanted to, they could not possibly reveal many of the aspects involved in this relationship (Pinheiro, Elali, \& Fernandes, 2008).

Observation of behavior in its natural environment is an alternative to address topics that, when discussed, can make a research participant feel embarrassed (Creswell, 2010). Its application can also reveal aspects of human behavior without the bias of social desirability, which is common in self-reports. A good example is the action of separating solid waste: observing garbage disposal behavior can reveal elements that are contrary to the data collected in an interview or questionnaire.

Observation can also be used when a researcher is facing a language barrier. One example is the study of Elsheshtawy (2013) about the social life of people in a low-income district in Dubai. According to the study, $93 \%$ of the population of the district (which had approximately 60,000 inhabitants, according to the census) was formed by immigrants from Bangladesh, India, The Philippines, and other countries. This precluded the use of interviews, on account of language barriers. Therefore, multiple observation methods were used: behavioral mapping, time-lapse video recording and photography.
The collected data, thus, outlined the panorama of social life which is established in the streets and corners.

Observation may be unsystematic, made in the natural environment where behaviors take place, without previously established categories or a systematized protocol. One can make records of the scene observed; it is useful in the preliminary stages of a research study, because it aids in instrument design, such as behavioral mapping, interviews and questionnaires. In turn, systematic observation uses a system of scores and categories that must be applied consistently. It requires the definition of behaviors and the place where behaviors will be observed and recorded (Sommer \& Sommer, 2002) as well as established time intervals. The observer's attitude also needs to be clear: it can be a participant observer whose role may be unknown or known by the group observed; a participant of the group who acts as an observer or a complete observer who does not participate but rather only observes (Creswell, 2010). Therefore, for observation to become a scientific method of research, the following dimensions have to be taken into account: the behavior to be observed, the environment, the elapsed time, the observer and the recording of observation (Bechtel \& Zeisel, 1987).

Although the direct observation method has advantages, it is limited to research of behaviors or signs of behavior; it is not used, for example, for research of attitudes, beliefs or opinions (Sommer \& Sommer, 2002). For this reason, the multi-method research strategy is very relevant. The combination of different techniques (e.g., direct observation, interviews and the quasi-experiment) allows a comprehensive investigation of person-environment interactions. Thus, the elements relative to the person and the aspects of physical space can be highlighted and understood in a reciprocal relationship.

This is why multi-methods are important to access both what concretely exists in the physical environment and what touches upon psychological phenomena and human behavior. Far from exhausting the possibilities of understanding the object under study, the multi-method approach 
is a strategy required in person-environment research, because it admits the complexity of reality. It is also a way to build the interdisciplinarity desired in these studies (Günther, Elali, \& Pinheiro, 2004; Pinheiro, 2003; Rivlin, 2003), as it combines research methods that are characteristic of different academic fields, such as Psychology, Architecture, Geography, Design, among others.

One of the major observational instruments used in person-environment studies is behavioral mapping (BM). It is an empirical document (i.e., the product of observation; Marušić \& Marušić, 2012), whose graphical representation of use and occupation of space allows the association between attributes of the environment, occurrence of observable behaviors and the time when they occur (Cosco, Moore, \& Islam, 2010; Goličnik \& Thompson, 2010; Marušić \& Marušić, 2012; Pinheiro et al., 2008).

The complexity of BM varies in accordance with the objectives of the research, which can focus on occurrences in a specific space - behaviors versus place (Pinheiro et al., 2008) - as well as on more complex forms of mapping which encompass behaviors, gender and approximate age of the observed, time of the day of occupancy, time of the week of occupancy, movement directions and even weather conditions (Marušić \& Marušić, 2012). It is not only a useful but also a low-cost method, especially if the research does not require video recording or photographic equipment, but rather observers that are skilled at writing protocols. However, while it is a useful and low-cost method, BM is time-consuming: it requires hours of observation and wait (Sommer \& Sommer, 2002).

BM is based on the concept of behavior setting, as formulated by Roger Barker. Behavior setting is understood as a natural environmental setting that organizes the occurrences of daily life. It is limited by space and time, and certain patterns of behavior or actions occur in it. For example: a class that takes place in the morning, a religious service that occurs from 7 to 8 p.m., a lecture, and so forth. The understanding of behavior setting implies that behaviors oc- cur within a somewhat specific pattern and are repeated in a reasonably stable pace, as regards the environment in which they occur (Carneiro \& Bindé, 1997; Cosco et al., 2010; Scott, 2005). Therefore, the construction of BM starts from the premise that the place of observation is a behavior setting or contains various settings, whose behaviors to be studied can be established in previous categories.

The design of a BM instrument implies preliminary observations that clearly define what is recorded, the map of the area, and the schedule of observations, in order to create a system to identify, codify and analyze the data (Marušić \& Marušić, 2012). In addition to observations, BM design can be based on data from interviews, database searches or conversations with informants. For example, in a survey conducted in a pre-school classroom, 37 interior designers have been interviewed with the purpose of categorizing the classrooms according to their spatial arrangement (Abbas \& Othman, 2010; i.e., the data of the interviews supported the design of the layout of the map). Another study performed in open spaces of an early childhood school relied on informants from the school itself (teachers, principals) and on data from a literature review to list the behavior categories of BM (Raymundo, Kuhnen, \& Soares, 2011).

$\mathrm{BM}$ can be used as an empirical document in research about social groups (Elsheshtawy, 2013), urban spaces (Gharib \& Salama, 2014; Goličnik \& Thompson, 2010; Luz \& Kuhnen, 2013; Ngesan \& Zubir, 2015), child development and school environment (Abbas \& Othman, 2010; Azlina \& Zulkiflee, 2012; Fernandes \& Elali, 2008; Ozdemir \& Yilmaz, 2008; Raymundo, Kuhnen, \& Soares, 2010, 2011; Smith et al., 2014) and in studies on use of leisure areas in apartment buildings (Latfi, Karim, \& Zahari, 2012). The tool can also be used to compile data in order to design proposals for intervention in environments. One example is the work of Kuhnen, Raymundo, and Guimarães (2011) in a child education classroom; data from BM was used to propose changes in the physical space of the classroom with the purpose of reducing con- 
flict in socialization among children. It should be noted that the above-mentioned studies have not exhausted all the possible applications of BM.

$\mathrm{BM}$ can be the only data collection instrument of a research study - with only one protocol of observation (Goličnik \& Thompson, 2010), two or more complementary protocols (Raymundo et al., 2010), or a protocol of observation associated with other techniques of the observation method (e.g., photographs and video recording; Abbas \& Othman, 2010; Elsheshtawy, 2013). Also, multiple data collection methods are often combined: BM associated with the interview method (e.g. Hussein, 2012; Ozdemir \& Yilmaz, 2008) and the survey method by means of questionnaires (e.g. Ngesan \& Zubir, 2015), for example.

The purpose of the present work is to discuss the BM technique through a review of empirical studies conducted between 2005 and 2015 . It analyzes the goals of each research, as well as the BM design developed to achieve the respective goals. This work discusses, in particular, the use of terms both abroad and in Brazil, bearing in mind that international studies make use of the term "behavioral mapping" but do not use the terms "place-centered" and "person-centered", which are found in the Brazilian literature. The terms used in Brazil may have an interpretative bias, in the sense that the technique may be applied in research steps that sometimes are focused on the environment, and sometimes on people. In practice, this is not always done: one can use "place-centered" maps when the application of the technique and the research objectives are oriented to people's behavior - hence the term no longer makes sense.

Therefore, the present discussion is very important in Brazil because it advocates the use of the same terms used abroad in an attempt to standardize them. In addition, it is assumed that the expression "behavioral mapping" is broad enough to encompass the varied applications of the technique, regardless of the intended objectives: a study with a greater focus on people (people in environments) or on environments (environments with people) or on the relationship between both of them (interaction).

\section{Place-Centered or Person-Centered Behavioral Mapping?}

The use of the terms "place-centered" and "person-centered", as types of behavioral mapping, follows the proposal of Sommer and Sommer (2002), who suggest that the techniques may serve different purposes. However, the authors have not explicitly stated that the two types are mutually exclusive. The description of the application, made by the authors, indicates that place-centered behavioral mapping makes use of a graphical representation of the study location, divided into sectors. Observation contains still scenes, as if they were photographs, with time-lapse recordings of behaviors and positions of people in each sector (in its most simplified version). The authors also suggest that this type of observation is more suitable for the study of a particular physical space, for example, the use that is made of it.

By contrast, person-centered behavioral mapping is described by Sommer and Sommer (2002) as a mode of observation that implies following the person observed in order to record their behavior, location and time. A person's pathway is represented graphically. More complex versions can include the recording of length of stay, detailed description of behaviors and detailed description of environments. According to the authors, this method is recommended for the study of groups, their social life, and of how and where they spend their time.

The description of Sommer and Sommer (2002) suggests that the place-centered behavioral map is more suitable for the study of places while the person-centered behavioral map, to study people, which may eventually raise some issues regarding the choice of the technique for the respective research objective:

The choice of mapping procedure will depend on the researcher's goals. If the objective is to access a particular location, such as usage of a store or a play area, placecentered methods are preferable. If the goal is to learn about a group or individuals, such as the social life of older people living by themselves, the observer will probably 
choose an individual-centered approach. (p. 64)

In light of this assumption, would it be relevant to use person-centered mappings in research whose goal is place-centered? On the other hand, could a study interested in aspects of social groups possibly rely of mappings whose focus is the environment? Do the terms in use derive strictly from a description of the method of application of the techniques, or do they bring implications concerning the objects and objectives of a study? Thus, this article encourages reflection about the objectives of the application of mappings according to the terms which they receive. For this purpose, below is an integrative review of literature that can support the discussion.

\section{The Use of Behavioral Mappings in Person-Environment Studies}

To outline the scenario of recent studies that have made use of BM, the selection of articles was focused on research conducted between 2005 and 2015. The criterion for selection of the databases was free and unlimited access to the articles and databases that serve as a repository of journals that publish person-environment studies. A search was performed in the international databases Science Direct and Sage Publications with the keywords "behavior mapping" and "behavioral mapping" on the title, abstract and keywords, and in the Brazilian databases SciELO and Pepsic with the descriptor "behavioral mapping" in all indices. A total of 20 articles were found. Their abstracts were read in order to exclude the studies that did not focus on behavioral mapping; after that, 14 studies were selected to be reviewed, as shown in Table 1 .

Five Brazilian articles were found. The others come mostly from Malaysia (5 articles), but there are also studies from the United Arab Emirates, Turkey, the United States and Turkey (one article from each country). All Brazilian studies come from university departments of Psychology and investigate children in their relationship with the outdoor space of education (Fernandes \& Elali, 2008; Raymundo et al.,
2010, 2011), the classroom (Kuhnen et al., 2011) or the public square (Luz \& Kuhnen, 2013). The foreign articles come from departments that address built environments, such as Architecture, Urban Planning, Interior Design and Engineering, with the exception of one article form the US (Smith et al., 2014), which comes from the field of Sociology and Anthropology. The following articles have focused on outdoor learning spaces (Azlina \& Zulkiflee, 2012; Hussein, 2012; Ozdemir \& Yilmaz, 2008; Smith et al., 2014), the classroom (Abbas \& Othman, 2010), and residential recreational areas (Latfi et al., 2012), in addition to streets and public parks (Elsheshtawy, 2013; Goličnik \& Thompson, 2010; Ngesan \& Zubir, 2015).

These research studies used the behavioral mapping technique to investigate relationships between socio-physical aspects of diverse environments and specific behaviors of users. The variables explained from environment included the behavior of childplay (Abbas \& Othman, 2010; Azlina \& Zulkiflee, 2012; Luz \& Kuhnen, 2013; Raymundo et al., 2010), social interaction (Abbas \& Othman, 2010; Fernandes \& Elali, 2008; Kuhnen et al., 2011; Raymundo et al., 2011), children's physical activity (Azlina \& Zulkiflee, 2012; Ozdemir \& Yilmaz, 2008; Smith et al., 2014); use behavior in spaces by children or adults (Elsheshtawy, 2013; Goličnik \& Thompson, 2010; Hussein, 2012; Latfi et al., 2012; Raymundo et al., 2011), place identity of users (Ngesan \& Zubir, 2015). For such studies, a multi-method approach was predominantly used; it associated naturalistic or unsystematic observations with behavioral mapping (Azlina \& Zulkiflee, 2012; Fernandes \& Elali; 2008; Hussein, 2012; Kuhnen et al., 2011; Raymundo et al., 2010, 2011), interviews (Azlina \& Zulkiflee, 2012; Elsheshtawy, 2013; Hussein, 2012; Kuhnen et al., 2011; Ozdemir \& Yilmaz, 2008), questionnaires (Latfi et al., 2012; Ngesan \& Zubir, 2015; Ozdemir \& Yilmaz, 2008) and documentary analysis (Elsheshtawy, 2013).

The authors of the studies described placecentered and person-centered applications of behavioral mapping. All foreign articles only used the term behavioral (or behavior) map (or 
Table 1

Result of Bibliographic Research

\begin{tabular}{|c|c|c|c|c|}
\hline Publication & $\begin{array}{l}\text { Country } \\
\text { of origin }\end{array}$ & $\begin{array}{l}\text { Department } \\
\text { of origin }\end{array}$ & $\begin{array}{c}\text { Location of } \\
\text { behavioral mapping }\end{array}$ & Theme or objective of study \\
\hline $\begin{array}{l}\text { Abbas \& Othman, } \\
2010\end{array}$ & Malaysia & $\begin{array}{l}\text { Person-Environment } \\
\text { Studies } \\
\text { Interior Design }\end{array}$ & Preschool classroom & $\begin{array}{l}\text { Relationship between design } \\
\text { of classrooms, social behavior } \\
\text { and chilplay }\end{array}$ \\
\hline $\begin{array}{l}\text { Azlina \& Zulkiflee, } \\
\qquad 2012\end{array}$ & Malaysia & Built Environment & $\begin{array}{l}\text { Outdoor spaces in } \\
\text { an early childhood } \\
\text { school }\end{array}$ & $\begin{array}{l}\text { Aspects of the school courtyard } \\
\text { that encourage physical activity } \\
\text { and play }\end{array}$ \\
\hline Elsheshtawy, 2013 & $\begin{array}{l}\text { United Arab } \\
\text { Emirates }\end{array}$ & $\begin{array}{l}\text { Architectural } \\
\text { Engineering }\end{array}$ & $\begin{array}{l}\text { Streets of a low- } \\
\text { income district }\end{array}$ & $\begin{array}{l}\text { Study on life in the streets in } \\
\text { low-income districts }\end{array}$ \\
\hline $\begin{array}{l}\text { Fernandes \& Elali, } \\
\qquad 2008\end{array}$ & Brazil & Psychology & $\begin{array}{l}\text { Outdoor spaces in } \\
\text { an early childhood } \\
\text { school }\end{array}$ & $\begin{array}{l}\text { Types of relationships of } \\
\text { children among themselves and } \\
\text { with the environment }\end{array}$ \\
\hline $\begin{array}{c}\text { Goličnik \& } \\
\text { Thompson, } 2010\end{array}$ & Slovenia & Urban Planning & $\begin{array}{l}\text { Mown grassed areas } \\
\text { in public parks }\end{array}$ & $\begin{array}{l}\text { Aspects of use of mown } \\
\text { grassed areas in a public park }\end{array}$ \\
\hline Hussein, 2012 & Malaysia & Architecture & Sensory Garden & $\begin{array}{l}\text { Use of the garden by children } \\
\text { with special needs }\end{array}$ \\
\hline Kuhnen et al., 2011 & Brazil & Psychology & $\begin{array}{l}\text { Early childhood } \\
\text { school classroom }\end{array}$ & $\begin{array}{l}\text { Intervention in the classroom } \\
\text { space to reduce the number of } \\
\text { conflicts }\end{array}$ \\
\hline Latfi et al., 2012 & Malaysia & $\begin{array}{l}\text { Architecture, Art and } \\
\text { Design }\end{array}$ & $\begin{array}{l}\text { Recreational area } \\
\text { in low-income } \\
\text { apartment buildings }\end{array}$ & $\begin{array}{l}\text { Children's leisure needs in } \\
\text { highly populated areas }\end{array}$ \\
\hline $\begin{array}{l}\text { Luz \& Kuhnen, } \\
\qquad 2013\end{array}$ & Brazil & Psychology & Public Square & $\begin{array}{l}\text { Characteristics of public spaces } \\
\text { that interfere in child behavior }\end{array}$ \\
\hline $\begin{array}{l}\text { Ngesan \& Zubir, } \\
2015\end{array}$ & Malaysia & $\begin{array}{c}\text { Person-Environment } \\
\text { Studies } \\
\text { Architecture }\end{array}$ & Public Park & Place identity in a public park \\
\hline $\begin{array}{l}\text { Ozdemir \& Yilmaz, } \\
2008\end{array}$ & Turkey & $\begin{array}{l}\text { Architecture } \\
\text { and Landscape } \\
\text { Architecture }\end{array}$ & $\begin{array}{l}\text { Open spaces for } \\
\text { recreation in a } \\
\text { primary school }\end{array}$ & $\begin{array}{l}\text { Association between physical } \\
\text { aspects of the school courtyard } \\
\text { and students' physical activity }\end{array}$ \\
\hline $\begin{array}{l}\text { Raymundo et al., } \\
2010\end{array}$ & Brazil & Psychology & $\begin{array}{l}\text { Open Spaces in } \\
\text { institution of early } \\
\text { childhood education }\end{array}$ & $\begin{array}{l}\text { Relationship between the } \\
\text { physical spaces and the jokes }\end{array}$ \\
\hline $\begin{array}{l}\text { Raymundo et al., } \\
2011\end{array}$ & Brazil & Psychology & $\begin{array}{l}\text { Open Spaces in an } \\
\text { early childhood } \\
\text { school }\end{array}$ & $\begin{array}{l}\text { Relationship between aspects } \\
\text { of the school courtyard, social } \\
\text { interactions and children's } \\
\text { activities }\end{array}$ \\
\hline Smith et al., 2014 & United States & $\begin{array}{l}\text { Sociology and } \\
\text { Anthropology }\end{array}$ & $\begin{array}{l}\text { Open Spaces in an } \\
\text { early childhood } \\
\text { school }\end{array}$ & $\begin{array}{l}\text { Outdoor recreational areas that } \\
\text { encourage physical activity }\end{array}$ \\
\hline
\end{tabular}

mapping), while the Brazilian articles made use of the terms proposed by Sommer and Sommer (2002). Only one publication from Malaysia (Ngesan \& Zubir, 2015) described, in the methodology section, the use of the placecentered technique; however, this expression was not associated with the term behavioral mapping. 
In order to check the behavioral mapping technique selected by each study - whether place-centered or person-centered - the emphasis given in each survey was identified. It was assumed that all studies have dealt with the personenvironment inter-relationship in its complexity. However, the researchers' background or the department of origin of the studies clearly show, to a greater or lesser degree, the emphasis given in each study as well as the choice of the theoretical framework and the objectives that had been set.

Thus, in various sections of the texts, evidence was sought of the focus that researchers have placed on their studies: place-centered (focus on people, groups, psychological processes and behavior) or place-centered (places and their characteristics, particular features and capabilities). Five female judges (four psychology researchers and one architecture researcher) performed this evaluation independently. They analyzed five elements in the text of each of the 14 articles: (a) information about the departments of origin of the study; (b) theoretical frameworks used by authors; (c) research question or research topic; (d) content of the discussion; (e) content of the final remarks.

Based on these criteria, and considering the emphasis used by the authors of the studies to communicate their investigations and considerations, the judges evaluated each study as having greater emphasis on person or on place. At the end of the evaluations, their opinions were compared, with a view to at least $80 \%$ of agreement among the judges (i.e., at least four of the five judges should agree with one another). For only one of the 14 articles, agreement $(60 \%)$ was below the expected rate. In order to reach the minimum level of agreement required, the judges were asked to review their evaluation of this particular article. In 10 cases, the judges had a consensual perception of the emphasis used by the authors in these studies. For the four remaining cases, the percentage of agreement was $80 \%$.

Table 2 shows the results of the judges' evaluations. As can be seen, 11 studies were considered to be place-centered while three of them were rated as person-centered. Table 2 also shows, for each article analyzed, the type of behavioral mapping technique used by the researchers, in order to allow a comparison of the types of technique and emphasis of each study. In five cases, the type of technique in use coincided with the focus of the study, that is, emphasis on the environment was matched with the use of the place-centered mapping technique, for example.

In the nine remaining cases, however, this match did not occur or took place in a different manner: four place-centered articles used the person-centered mapping technique; three articles whose focus was people used the place-centered mapping method; and, finally, two works that were perceived by the judges as having an emphasis on the environment have used not only the place-centered technique but also records of pathways and behaviors of specific individuals as they moved through space. The cases of nonmatch between the emphasis of research and the technique whose name suggests "person" or "place" are shown below.

A study conducted in Kuala Lumpur (Hussein, 2012) about the use of sensory gardens with children with special educational needs, investigated the aspects of the physical environment (affordances) which offered more or less physical-sensory stimulation and social interactions among children. BM was used to record children's pathways, preferences, time spent in each sector of the garden and the affordances of each environment. In this case, the record of children's pathways provided data to investigate the suitability of the environment (i.e., the place-centered technique served a purpose to the environment-oriented research).

Goličnik and Thompson (2010) investigated aspects of use of an urban park with a focus on mown grassed areas and layout of gardens and walks. For such purpose, they applied BM by overlaying the positions of people who stood still by the sectors of the park, as well as the pathways of users who went walking, bicycling or skating. It should be noted that the use of this technique has characteristics of both the personcentered map and the place-centered map, as defined by Sommer and Sommer (2002), and the 
Table 2

Comparison between Type of Behavioral Mapping and Emphasis of Study

\begin{tabular}{lccc}
\hline Publication & $\begin{array}{c}\text { Type of behavioral } \\
\text { mapping }\end{array}$ & $\begin{array}{c}\text { The emphasis } \\
\text { of the study }\end{array}$ & $\begin{array}{c}\text { Concordance between } \\
\text { judges regarding } \\
\text { the emphasis }\end{array}$ \\
\hline Abbas \& Othman, 2010 & Place-centered & Place & $100 \%$ \\
Azlina \& Zulkiflee, 2012 & Person-centered & Place & $100 \%$ \\
Elsheshtawy, 2013 & Place-centered & Person & $80 \%$ \\
Fernandes \& Elali, 2008 & Person-centered & Place & $80 \%$ \\
Goličnik \& Thompson, 2010 & Place-centered and Person-centered & Place & $100 \%$ \\
Hussein, 2012 & Person-centered & Place & $100 \%$ \\
Kuhnen et al., 2011 & Place-centered & Place & $100 \%$ \\
Latfi et al., 2012 & Place-centered & Place & $100 \%$ \\
Luz \& Kuhnen, 2013 & Person-centered & Place & $100 \%$ \\
Ngesan \& Zubir, 2015 & Place-centered & Person & $80 \%$ \\
Ozdemir \& Yilmaz, 2008 & Place-centered & Place & $80 \%$ \\
Raymundo et al., 2010 & Place-centered and Person-centered & Place & $100 \%$ \\
Raymundo et al., 2011 & Place-centered & Person & $100 \%$ \\
Smith et al., 2014 & Place-centered & Place & $100 \%$ \\
\hline
\end{tabular}

emphasis of the research is directed to the characterization of the place.

By contrast, in the research by Ngesan and Zubir (2015), BM was used with previously defined sectors and behaviors, as well as with fixed points of observation, in order to investigate the psychological phenomenon of place identity in night goers of two public squares in Malaysia. The results of BM were combined with the application of questionnaires. Another study, conducted on the streets and corners of a low-income district in Dubai, made use of photographs, timelapse video recording, behavioral mapping with regular observations and recording of density and use of areas, with the goal of understanding the social life of groups of immigrants who settled in that region (Elsheshtawy, 2013).

The studies conducted in school courtyards (Azlina \& Zulkiflee, 2012; Fernandes \& Elali, 2008; Raymundo et al., 2010, 2011) and in public squares (Luz \& Kuhnen, 2013) are good examples of research studies whose objectives or hypotheses include aspects of the people and the environment in an interwoven and interdependent manner: the absence of one would imply the non-existence of the other. Even though some studies had more emphasis on the discussion about the person or the environment, all of them showed concern in understanding the relationship between children and their spaces and the implication of the latter in social relationships, physical activities or health conditions. To meet the objectives of the studies, the researchers have developed different BM protocols, combined and superimposed, formed by double entry tables, by maps or by a combination of both, including sector-based observation and observation of children's pathways.

It was found that most studies showed no match between research objectives and type of technique in use. In other words, place-centered studies used the person-centered technique and vice versa. The nine studies that showed no match between the technique and emphasis of the research gave rise to the present discussion about the proposal of Sommer and Sommer 
(2002), whereby these authors suggested associating the characteristics of mapping application with research objectives. Thus, one may raise questions about the terms in use, particularly, in Brazilian publications: do they result strictly from a description of the method for applying the techniques or do they have implications with respect to the objectives of the study? To what extent has the proposal of Sommer and Sommer (2002) influenced the choice of techniques applied in Brazil?

The review of literature between the years 2005 and 2015 shows that the studies using behavioral mapping are concerned in designing the research problem, and the instrument is designed based on the hypotheses or objectives, ranging from lean protocols (with records of sector/time/ number of people) to more complex protocols composed of time, number of people, preferences, participants' characteristics, physical characteristics of the environment, GPS location, pathway layouts, direction, length of stay, affordances, among others. The international articles do not use the terms "person-centered" or "place-centered". They only seek to describe how the technique was applied to meet the objectives of the study, which may be more concerned with research on places with people, or people in places or, finally, the interaction between people and places.

\section{Final Remarks}

The aim of this article was to discuss the technique of BM. For such purpose, a review was made of empirical studies conducted between 2005 and 2015. There is a difference in use of terms in Brazil and abroad, considering that only the Brazilian studies have used the expressions "place-centered" and "person-centered" to differentiate the types of BM.

If research is to be disseminated both at the Brazilian and the international levels, the adoption of the term "behavioral mapping" should be sufficient as well as comprehensive, both as regards methodology and objectives or hypotheses of the study. The review of the studies revealed the possibility of using mixed techniques of be- havioral mapping, which have characteristics of the "centered in place" and "person-centered" techniques in accordance with the needs and interests of researchers. Thus, is it necessary to create a third category of BM, with a mixed nature? Or could we simply adopt the term "behavioral mapping", as it offers multiple possibilities of applying the technique, wherein each researcher may develop a particular research design?

All things considered, we suggest the use of the term "behavioral mapping" and highlight the importance of describing the technique design in detail as regards the objectives, as currently done by international research groups. Apart from techniques, it can also be said that personenvironment studies, in spite of the challenges inherent in the investigation of inter-relationships, seek to achieve interdisciplinarity through methodologies that allow research on the person, on the environment and on the person-environment interaction as well. Just like when someone focuses on a camera, focus during data collection is changed in order to attempt to capture the complexity of the phenomenon, hence the design of the data collection instrument is defined according to the research question.

\section{Authors' Contributions}

Substantial contribution in the concept and design of the study: Camila Klein

Contribution to data collection: creio que não se aplica pois é um artigo metodológico

Contribution to data analysis and interpretation: Camila Klein, Ariane Kuhnen, Maíra Longhinotti Felippe, Bettieli Barbosa da Silveira

Contribution to manuscript preparation: $\mathrm{Ca}-$ mila Klein, Ariane Kuhnen, Maíra Longhinotti Felippe, Bettieli Barbosa da Silveira

Contribution to critical revision, adding intelectual content: Camila Klein, Ariane Kuhnen, Maíra Longhinotti Felippe, Bettieli Barbosa da Silveira

\section{Conflicts of interest}

The authors declare that they have no conflict of interest related to the publication of this manuscript. 


\section{References}

Abbas, M. Y., \& Othman, M. (2010). Social Behavior preschool children in relation to physical spatial definition. Procedia Social and Behavioral Sciences, 5, 935-941.

Azlina, W., \& Zulkiflee, A. S. (2012). A pilot study: The impact of outdoor play spaces on kindergarten children. Procedia Social and Behavioral Sciences, 38, 275-283.

Bechtel, R. B., \& Zeisel, J. (1987). Observation: The world under a glass. In R. B. Bechtel, R. W. Marans, \& W. Michelson (Eds.), Methods in Environmental and Behavioral Research (pp. 11-40). New York: VNR Company.

Carneiro, C., \& Bindé, P. J. (1997). A psicologia ecológica e o estudo dos acontecimentos da vida diária. Estudos de Psicologia (Natal), 2(2), 277-285. doi: http://dx.doi.org/10.1590/S1413$-294 X 1997000200010$

Corral-Verdugo, V., \& Pinheiro, J. Q. (1999). Condições para o estudo do comportamento pró-ambiental. Estudos de Psicologia (Natal), 4(1), 7-22. doi: http://dx.doi.org/10.1590/S1413$-294 X 1999000100002$

Cosco, N. I., Moore, R. C., \& Islam, M. (2010). Behavior mapping: A method for linking preschool physical activity and outdoor design. Medicine \& Science in Sports \& Exercise, 513-519.

Creswell, J. (2010). Projeto de Pesquisa: Métodos qualitativo, quantitativo e misto. Porto Alegre, RS: Artmed.

Elsheshtawy, Y. (2013). Where the sidewalk ends: Informal street corner encounters in Dubai. $\mathrm{Ci}$ ties, 31, 382-393.

Fernandes, O. S., \& Elali, G. A. (2008). Reflexões sobre o comportamento infantil em um pátio escolar: O que aprendemos observando as atividades das crianças. Paidéia (Ribeirão Preto), 18(39), 41-52. doi: http://dx.doi.org/10.1590/ S0103-863X2008000100005

Gharib, R. Y., \& Salama, A. M. (2014). Nature of urban interventions in changing the old center of globalizing Doha. Frontiers of Architectural Research, 3, 468-476.

Goličnik, B., \& Thompson, C. (2010). Emerging relationships between design and use of urban park spaces. Landscape and Urban Planning, $94,38-53$.
Günther, H., Elali, G., \& Pinheiro, J. (2004). A abordagem multimétodos em Estudos Pessoa-ambiente: Características, definições e implicações. Textos de Psicologia Ambiental, 23, 1-9.

Günther, H., Elali, G. A., \& Pinheiro, J. Q. (2008). A abordagem multimétodos em estudos pessoa-ambiente: Características, definições e implicações. In J. Q. Pinheiro \& H. Günther (Eds.), Métodos de pesquisa nos estudos pessoa-ambiente (pp. 369-396). São Paulo, SP: Casa do Psicólogo.

Günther, I. A. (2008). O uso da entrevista na interação pessoa-ambiente. In J. Q. Pinheiro \& H. Günther (Eds.), Métodos de pesquisa nos estudos pessoa-ambiente (pp. 53-74). São Paulo, SP: Casa do Psicólogo.

Hussein, H. (2012). The influence os sensory gardens on the behavior of children with special educational needs. Procedia Social and Behavioral Sciences, 38, 343-354.

Kuhnen, A., Raymundo, L. S., \& Guimarães, A. M. F. (2011). A linguagem do espaço físico na educação infantil. Barbarói, 35, 109-127.

Latfi, M. F. M., Karim, H. A., \& Zahari, S. S. (2012). Compromising the recreational activities of children in low cost flats. Procedia Social and Behavioral Sciences, 50, 791-799.

Luz, G. M., \& Kuhnen, A. (2013). O uso dos espaços urbanos pelas crianças: Explorando o comportamento do brincar em praças públicas. Psicologia: Reflexão e Crítica, 26(3), 552-560.

Marušić, B. G., \& Marušić, D. (2012). Behavioural Maps and GIS in Place Evaluation and Design. In B. M. Alam (Ed.), Application of Geographic Information Systems. doi: 10.5772/47940. Retrieved from http:/www.intechopen.com/books/ application-of-geographic-information-systems/ behavioural-maps-and-gis-in-place-evaluationand-design

Ngesan, M. R., \& Zubir, S. S. (2015). Place identity of nightie urban public park in Shah Alam and Putrajaya. Procedia Social and Behavioral Sciences, 170, 452-462.

Ozdemir, A., \& Yilmaz, O. (2008). Assessment of outdoor school environments and physical activity in Ankara's primary schools. Journal of Environmental Psychology, 28, 287-300.

Pinheiro, J. Q. (2003). Psicologia Ambiental brasileira no início do século XXI: Sustentável? In O. 
H. Yamamoto \& V. V. Gouveia, Construindo a psicologia brasileira: Desafios da ciência e prática psicológica (pp. 280-313) São Paulo, SP: Casa do Psicólogo.

Pinheiro, J. Q., Elali, G. A., \& Fernandes, O. S. (2008). Observando a interação pessoa-ambiente: Vestígios ambientais e mapeamento comportamental. In J. Q. Pinheiro \& H. Günther (Eds.), Métodos de pesquisa nos estudos pessoa-ambiente (pp. 75-104). São Paulo, SP: Casa do Psicólogo.

Raymundo, L. S., Kuhnen, A., \& Soares, L. B. (2010). O espaço aberto na educação infantil: Lugar para brincar e desenvolver-se. Psicologia em Revista, 16(2), 251-270.

Raymundo, L. S., Kuhnen, A., \& Soares, L. B. (2011). Mapeamento comportamental: Observação de crianças no parque da préescola. Paidéia (Ribeirão Preto), 21(50), 431435. doi: http://dx.doi.org/10.1590/S0103863X2011000300016

Rivlin, L. G. (2003). Olhando o passado e o futuro: Revendo pressupostos sobre as interrelações pessoa-ambiente. Estudos de Psicologia (Natal), 8(2), 215-220. doi: http://dx.doi.org/10.1590/ S1413-294X2003000200003
Saramago, J. (2005). Ensaio sobre a cegueira. São Paulo, SP: Cia das Letras.

Scott, M. M. (2005). A powerful theory and a paradox: Ecological psychologists after Barker. Environment and Behavior, 37(3), 295-329.

Smith, W. R., Moore, R., Cosco, N., Wesoloski, J., Danninger, T.,Ward, D. S., Trost, S. G., \& Ries, N. (2014). Increasing physical activity in childcare outdoor learning environments: The effect of setting adjacency relative to other built environments and social factors. Environment and Behavior, 1-29.

Sommer, R., \& Sommer, B. (2002). A practical guide to behavioral research: Tools and techniques. New York: Oxford Press.

Received: 11/08/2016

$1^{\text {st }}$ revision: 06/04/2017 Accepted: 09/04/2017

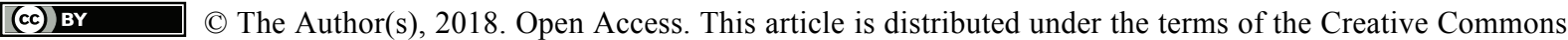
Attribution 4.0 International License (http://creativecommons.org/licenses/by/4.0/), which permits unrestricted use, distribution, and reproduction in any medium, provided you give appropriate credit to the original author(s) and the source, provide a link to the Creative Commons license, and indicate if changes were made. 